\title{
Short Communication: Bird community and it's conservation implications in Gunung Tunak Nature Park, Lombok, Indonesia
}

\author{
GITO HADIPRAYITNO ${ }^{1, \vartheta}$, AGIL AL IDRUS ${ }^{1}$, I GDE MERTHA ${ }^{1}$, M. LIWA ILHAMDI ${ }^{1}$, I WAYAN SUANA ${ }^{2}$ \\ ${ }^{1}$ Program of Biology Education, Faculty of Teacher Training and Education Science, Universitas Mataram. Jl. Majapahit No. 62, Mataram 83125, West \\ Nusa Tenggara, Indonesia. Tel.: +62-370-623873, ”email: gitohadiprayitno@unram.ac.id \\ ${ }^{2}$ Department of Biology, Faculty of Mathematics and Natural Sciences, Universitas Mataram. J1. Majapahit No. 62, Mataram 83125, West Nusa \\ Tenggara, Indonesia
}

Manuscript received: 6 May 2019. Revision accepted: 29 May 2019.

\begin{abstract}
Hadiprayitno G, Al Idrus A, Mertha IG, Ilhamdi ML, Suana IW. 2019. Birds community and it's conservation implications in Gunung Tunak Nature Park, Lombok, Indonesia. Biodiversitas 20: 1753-1757. Bird community is an important indicator of ecosystem health. A study was conducted in Gunung Tunak Nature Park to analyze the composition of bird species and the abundance and diversity of bird species. Data were collected by survey method from May to August 2017 on three trails. The bird fauna of Gunung Tunak Nature Park consisted of 32 species belonging to 27 families and 10 orders. The order Passeriformes accounted for the dominant family and species, with an abundance of $61.6 \%$. The species with the highest abundance is Zosterops chloris (13.9\%), following by Orthotomus sepium (12.2\%), and Streptopelia chinensis (10.4\%). While the diversity index was 3.03, indicating that the bird community in Gunung Tunak Nature Park is still well preserved. Five species are of high conservation priority based on protected by Indonesian Law, Endemicity of Wallacea, and the IUCN Red list i.e., Megapodius reinwardt, Pitta elegans, Caloenas nicobarica, Lalage sueurii, and Dicrurus densus.
\end{abstract}

Keywords: Abundance, bird, conservation, diversity, Gunung Tunak Nature Park

\section{INTRODUCTION}

Many ecosystems in the world - forests, waters, wetlands, mangroves, coastal, marine, and other important ecosystems - are experiencing pressure due to rapid population growth and economic development. Ecosystem changes have occurred on a very large scale in the last 10 years, due to a combination of causes such as climate change, natural resource exploitation, pollution, habitat destruction and the presence of invasive species (Leadley et al. 2014; Barnosky et al. 2012; Hughes et al. 2013). Ecosystem change also causes loss of biodiversity (Hooper et al. 2012).

Conservation efforts are needed to reduce the damage and changes in ecosystems. Nature Park is an effort to protect and conserve an area that can provide a guarantee of its biodiversity of flora and fauna. Based on Law No. 5 of 1990 on the Conservation of Biological Resources and Ecosystems Republic of Indonesia, nature parks are included in nature conservation areas that require tourism activities to comply with the principles of conservation and protection of nature. Nature parks can also be used for the advancement of education and science. Biological resources that exist in these areas should be sustainably used (Ministry of Forestry Republic of Indonesia, 2013).

Gunung Tunak Nature Park has been inaugurated since 1996. It is one of the nature parks in Lombok, Indonesia that has an important role in protecting biodiversity in the area of Gunung Tunak. However, the legalization of this area is not followed by inventory and monitoring of biodiversity, especially the bird community. Bird community is essential in monitoring both habitat and biodiversity changes (Andrén 1994; Palmer et al. 2008). Due to sensitivity to environmental changes, bird communities can be used to evaluate trends and environmental changes (Lindenmayer et al. 2000; Liu et al. 2004; Reis et al. 2012). In addition, bird diversity can be a very important estimator for ecological conditions (Larsen et al. 2011). In addition to very important ecological value, the aesthetic values of birds (the beauty of feather color, sound, and behavior) are important to support the activities of ecotourism in ecotourism area (Tripathi et al. 2015) likewise in Gunung Tunak Nature Park.

Currently, there is no scientific information about the bird community in Gunung Tunak Nature Park. Scientific information is an indicator of the effectiveness of long-term conservation efforts. The effectiveness of conservation is often measured by species diversity, with a current focus on changing aspects of diversity such as functional, genetic, and phylogenetic traits that have capacity to disclose processes that underlie patterns in a community composition (Luck et al. 2013; Lindenmayer et al. 2015; Dias et al. 2016). Thus, information on bird community in Gunung Tunak Nature Park is needed as one of the important efforts to conserve the bird community and its habitat. 


\section{MATERIALS AND METHODS}

\section{Study area}

Gunung Tunak Nature Park is located on Mertak Village at $8.533^{\circ} \mathrm{S} 116.240^{\circ} \mathrm{E}$, Central Lombok District, West Nusa Tenggara, Indonesia (Figure 1). The park has dry deciduous lowland monsoon forest with the altitude ranged from 0 to $105 \mathrm{~m}$. According to the SchmidtFerguson classification, Gunung Tunak Nature Park has a C, D and E climate type. The rainy season is generally from September to April (Wahyuni and Mildranaya 2010).

\section{Sampling procedure}

Data were collected by survey methods (Howes et al. 2003), on three trails. All of the trails started from the guesthouse: trail 1 to the Bile Sayak Beach $(3 \mathrm{~km})$, trail 2 to Ujung Beach $(2.26 \mathrm{~km})$, and trail 3 to the entrance of Gunung Tunak Nature Park $(1.9 \mathrm{~km})$. Survey was carried out twice a month from May to October 2017 by walking down the trails in the morning (06:00 to 10:00) and in the afternoon (16:00 - 18:00) to identify and count the number of individuals of each species. Bird species were identified using the field guide by Coates and Bishop (2000).

\section{Data analysis}

Community analysis was done through relative abundance analysis and diversity analysis. Relative abundance analysis was according to the equation (Krebs, 2009):

$$
\mathrm{RAD}=(\mathrm{ni} / \mathrm{N}) \times 100 \%
$$

Where,

RAD: relative species abundance

ni : number of individual species-i

$\mathrm{N}$ : total number of individuals.
Diversity analysis was performed using ShannonWiener Diversity Index, with formula:

$$
\mathrm{H}^{\prime}=-\sum_{i=1}^{s} p i \ln p i
$$

Where,

$\mathrm{H}$ ': diversity index

$p i$ : proportional abundance

\section{RESULTS AND DISCUSSION}

\section{Bird species composition}

A total of 32 species of birds belonging to 27 families and 10 orders were recorded in Gunung Tunak Nature Park (Fig. 2). The order Passeriformes accounted for the largest number of families and species, with 15 species or $46 \%$. Passeriformes has also been found to be dominant in a conservation area adjacent to the oceans (Manica et al. 2010; Zakaria and Rajpar 2015; Li et al. 2016; Roy et al. 2016). Higgins et al. (2001) explained that Passeriformes is the largest order and most diverse, with 5,712 species and 45 families.

In general, the bird community in Gunung Tunak Nature Park can be grouped into terrestrial birds and waterbirds. Most of them, 29 species or $91 \%$, were terrestrial birds. Waterbirds only consisted of three species, Egretta garzetta, E. sacra, and Phaethon lepturus (Fig. 2). The dominance of terrestrial birds is due to hills and forests, making up large parts of Gunung Tunak Nature Park (Wahyuni and Mildranaya 2010) which are ideal habitats for terrestrial birds.
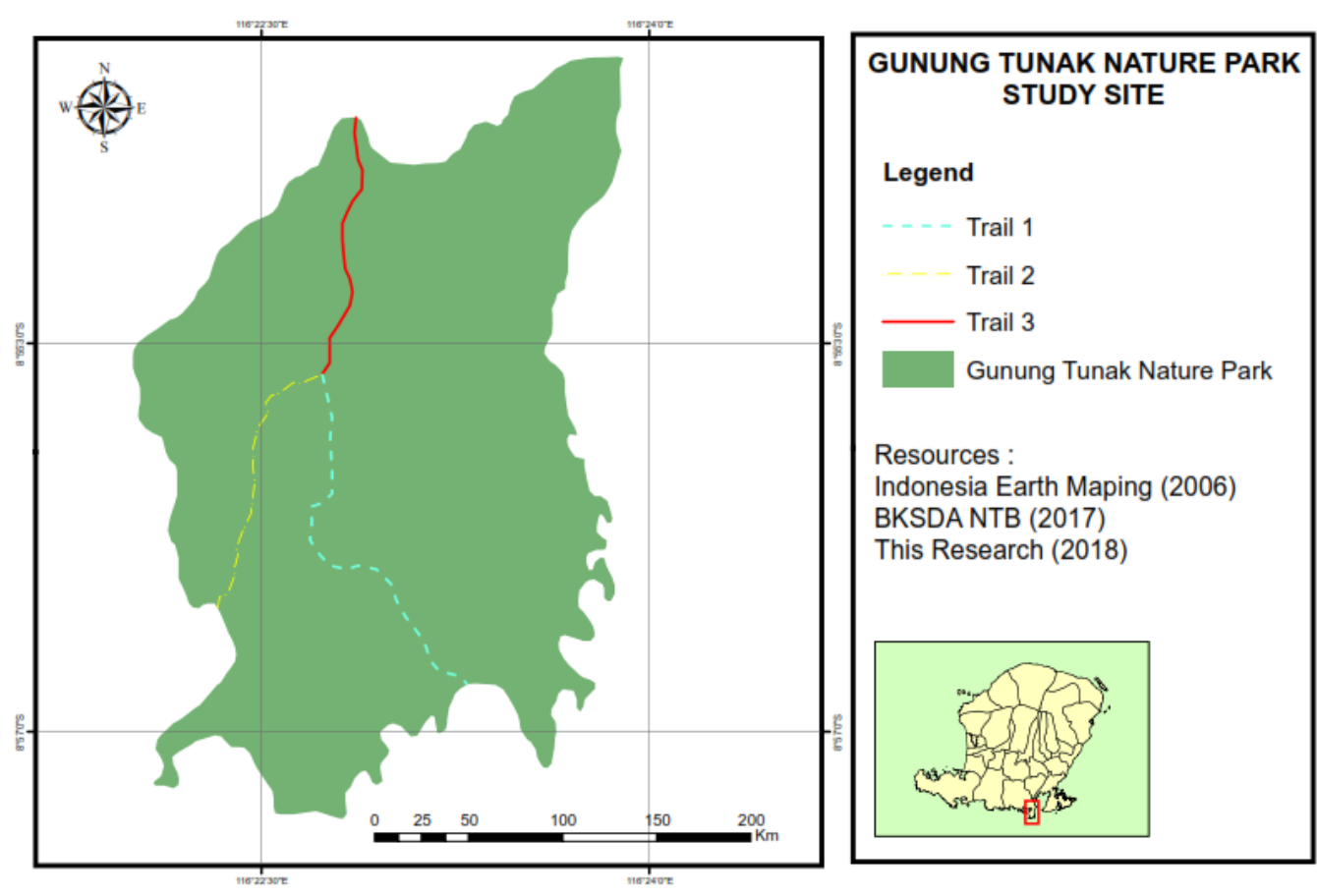

Figure 1. Study sites at Gunung Tunak Nature Park, Lombok, Indonesia 


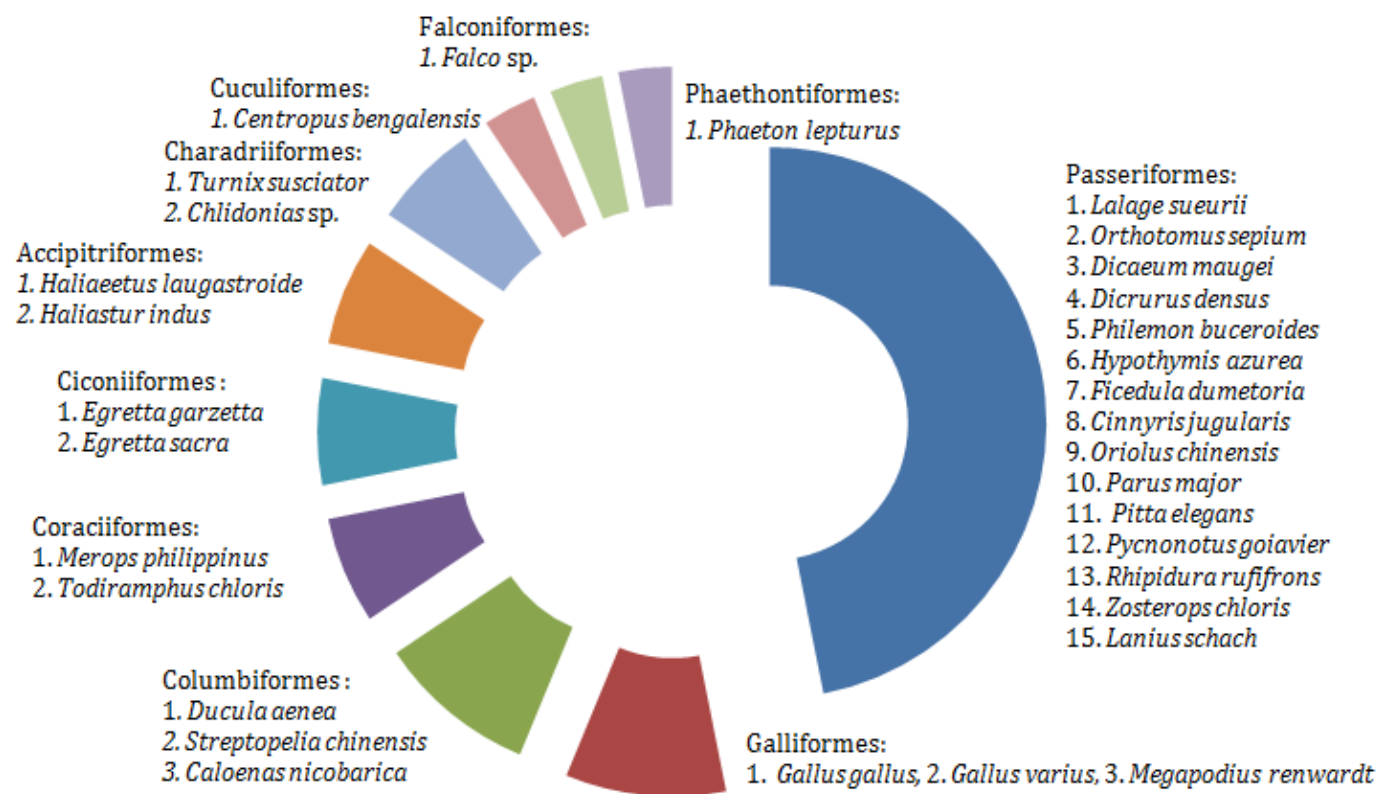

Figure 2. Orders and species of birds in Gunung Tunak Nature Park, Lombok, Indonesia

Table 1. Abundance and conservation status of bird in Gunung Tunak Nature Park, Lombok, Indonesia

\begin{tabular}{|c|c|c|c|c|c|c|c|}
\hline \multirow[b]{2}{*}{ Species } & \multirow[b]{2}{*}{ English Name } & \multirow[b]{2}{*}{ Family } & \multirow{2}{*}{$\begin{array}{c}\text { Individual } \\
\text { number }\end{array}$} & \multirow{2}{*}{$\begin{array}{c}\text { RAD } \\
(\%)\end{array}$} & \multicolumn{3}{|c|}{ Conservation Status } \\
\hline & & & & & $\begin{array}{c}\text { Permenlhk } \\
106 / 2018\end{array}$ & IUCN & $\begin{array}{l}\text { Wallacea } \\
\text { endemicity }\end{array}$ \\
\hline Haliaeetus leucogaster & White-bellied Sea Eagle & Accipitridae & 36 & 0.9 & $\mathrm{P}$ & $\mathrm{LC}$ & $\mathrm{NE}$ \\
\hline Haliastur indus & Brahminy Kite & Accipitridae & 16 & 0.4 & $\mathrm{P}$ & $\mathrm{LC}$ & NE \\
\hline Todiramphus chloris & Collared Kingfisher & Alcedinidae & 192 & 4.8 & NP & $\mathrm{LC}$ & $\mathrm{NE}$ \\
\hline Egretta garzetta & Little Egret & Ardeidae & 16 & 0.4 & NP & $\mathrm{LC}$ & $\mathrm{NE}$ \\
\hline Egretta sacra & Pacific Reef-egret & Ardeidae & 36 & 0.9 & NP & $\mathrm{LC}$ & $\mathrm{NE}$ \\
\hline Lalage sueurii & White-shouldered Triller & Campephagidae & 104 & 2.6 & NP & $\mathrm{LC}$ & E \\
\hline Orthotomus sepium & Olive-backed Tailorbir & Cisticolidae & 488 & 12.2 & NP & $\mathrm{LC}$ & $\mathrm{NE}$ \\
\hline Caloenas nicobarica & Nicobar Pigeon & Columbidae & 68 & 1.7 & $\mathrm{P}$ & NT & $\mathrm{NE}$ \\
\hline Ducula aenea & Green Imperial-pigeon & Columbidae & 68 & 1.7 & NP & $\mathrm{LC}$ & NE \\
\hline Streptopelia chinensis & Spotted dove & Columbidae & 416 & 10.4 & NP & $\mathrm{LC}$ & $\mathrm{NE}$ \\
\hline Centropus bengalensis & Lesser Coucal & Cuculidae & 52 & 1.3 & NP & $\mathrm{LC}$ & NE \\
\hline Dicaeum maugei & Red-chested Flowerpecker & Dicaeidae & 68 & 1.7 & NP & $\mathrm{LC}$ & NE \\
\hline Dicrurus densus & Wallacean Drongo & Dicruridae & 140 & 3.5 & NP & $\mathrm{LC}$ & $\mathrm{E}$ \\
\hline Falco sp. & Falcon & Falconidae & 36 & 0.9 & $\mathrm{P}$ & $\mathrm{LC}$ & NE \\
\hline Lanius schach & Long-tailed Shrike & Laniidae & 104 & 2.6 & NP & $\mathrm{LC}$ & $\mathrm{NE}$ \\
\hline Megapodius reinwardt & Orange-footed Scrubfowl & Megapodiidae & 88 & 2.2 & $\mathrm{P}$ & LC & NE \\
\hline Philemon buceroides & Helmeted Friarbird & Meliphagidae & 36 & 0.9 & NP & $\mathrm{LC}$ & NE \\
\hline Merops philippinus & Blue-tailed Bee-eater & Meropidae & 172 & 4.3 & NP & $\mathrm{LC}$ & $\mathrm{NE}$ \\
\hline Hypothymis azurea & Black-naped Monarch & Monarchidae & 16 & 0.4 & NP & $\mathrm{LC}$ & $\mathrm{NE}$ \\
\hline Ficedula dumetoria & Rufous-chested Flycatcher & Muscicapidae & 16 & 0.4 & NP & $\mathrm{LC}$ & NE \\
\hline Cinnyris jugularis & Olive-backed Sunbird & Nectariniidae & 192 & 4.8 & NP & $\mathrm{LC}$ & NE \\
\hline Oriolus chinensis & Oriolus chinensis & Oriolidae & 104 & 2.6 & NP & $\mathrm{LC}$ & $\mathrm{NE}$ \\
\hline Parus major & Great Tit & Paridae & 172 & 4.3 & NP & $\mathrm{LC}$ & NE \\
\hline Phaethon lepturus & White-tailed Tropicbird & Phaethontidae & 16 & 0.4 & $\mathrm{P}$ & $\mathrm{LC}$ & $\mathrm{NE}$ \\
\hline Gallus gallus & Red Junglefowl & Phasianidae & 36 & 0.9 & NP & $\mathrm{LC}$ & $\mathrm{NE}$ \\
\hline Gallus varius & Green Junglefowl & Phasianidae & 120 & 3.0 & NP & $\mathrm{LC}$ & NE \\
\hline Pitta elegans & Elegant Pitta & Pittidae & 120 & 3.0 & $\mathrm{P}$ & $\mathrm{LC}$ & $\mathrm{NE}$ \\
\hline Pycnonotus goiavier & Yellow-vented Bulbul & Pycnonotidae & 244 & 6.1 & NP & $\mathrm{LC}$ & $\mathrm{NE}$ \\
\hline Chlidonias sp. & Marsh tern & Sternidae & 88 & 2.2 & $\mathrm{P}$ & $\mathrm{LC}$ & NE \\
\hline Rhipidura rufifrons & Rufous Fantail & Rhipiduridae & 104 & 2.6 & NP & $\mathrm{LC}$ & $\mathrm{NE}$ \\
\hline Turnix suscitator & Barred Buttonquail & Turnicidae & 68 & 1.7 & NP & $\mathrm{LC}$ & $\mathrm{NE}$ \\
\hline Zosterops chloris & Lemon-bellied White-eye & Zosteropidae & 556 & 13.9 & NP & $\mathrm{LC}$ & NE \\
\hline Total & & & 3988 & 100 & & & \\
\hline
\end{tabular}

Note: P: Protected; NP: Not Protected; LC: Least Concern; NT: Near Threatened; E: Endemic; NE: Non-Endemic 


\section{Abundance, diversity and conservation status of bird species}

The survey found that Zosterops chloris, Orthotomus sepium, and Streptopelia chinensis has RAD >10\%. Other species such as Lalage sueurii, Dicrurus densus, Pitta elegans, Megapodius reinwardt, Caloenas nicobarica, Haliaeetus leucogastroides, Haliastur indus, Chlidonias sp., Caloenas nicobarica, and Falco sp. are included on three categories of conservation status, Permenlhk 106 Tahun 2018, IUCN Red list status, and endemicity.

\section{Discussion}

Based on Table 1, the species with the highest abundance is Zosterops chloris. It is caused by Zosterops has a diverse diet, in which feeding more on fruits and nectar, but may also feed on insects (Fry et al. 2000). In addition, species of Zosterops generally have similar habitat and food and can continue to grow in spite of the dense population (Catterall 1985; Scott et al. 2003). The colonization pattern of Zosterops also influences its high abundance in Gunung Tunak Nature Park. Zosterops are often found in small groups and have remarkable abilities in forming colony formations in an area and have the ability to form an endemic formation on an island (Hockey et al. 2005; Warren et al. 2006; Moyle et al. 2009; Melo et al. 2011).

Passeriformes dominate bird abundance in Gunung Tunak Nature Park with a relative abundance of $61.6 \%$. The dominance of Passeriformes is due to variations in life ability and diverse food sources. Passeriformes can live arboreally or terrestrially, even though there are families that specifically live in arboreal habitats such as Hirundinidae or in terrestrial habitats such as Menuridae and Pittidae (Higgins et al. 2001). Furthermore, they can feed on almost all types of food, from plants to vertebrates (Higgins et al. 2001). However, most of them tend to specialize in foods, such as families that feed on nectar (Nectariniidae), seeds (Passeridae), fruits (Zosteropidae), small vertebrates (Artamidae), and insects (Maluridae, Pardalotidae, Petroicidae, and others).

The Shannon-Wiener Diversity Index of the bird community in Gunung Tunak Nature Park was 3.03. The value of the Shannon-Wiener Diversity Index usually ranges from 1.5 to 3.5 and very rarely reaches 4.5 . Communities whose species abundance is assumed to be normally distributed as in birds, copepods, planktons, coral reefs, and plants, or communities with abundant models of Broken Sticks, will have the value of Shannon-Wiener Diversity Index ranging from 1 to 3 (May 1975). Thus, the value of 3.03 obtained in the bird community in Gunung Tunak Nature Park was the maximum value of a bird community; it is certain that the bird community in Gunung Tunak Nature Park is still well preserved.

Gunung Tunak Nature Park is an excellent habitat for bird communities. This is evident in the habitat's ability to support the presence of 32 bird species. As bird community can be used as an indicator of ecosystem health and biodiversity (Gregory et al. 2003), conservation of bird communities in Gunung Tunak Nature Park is increasingly important, especially the presence of 14 species with high conservation value, namely Lalage sueurii, Dicrurus densus, Pitta elegans, Megapodius reinwardt, Caloenas nicobarica, , Haliaeetus leucogastroides, Haliastur indus, Chlidonias sp., Caloenas nicobarica, and Falco sp.

Caloenas nicobarica is a species with Near Threatened status (Birdlife International, 2012). Previous studies did not report it in Lombok (Myers and Bishop 2005; Suana et al. 2016; Hadiprayitno et al. 2016), so it is a new record for Lombok. The existence of $C$. nicobarica in some places of Indonesia has been reported by several researchers (Rahayuningsih et al. 2007; Mittermeier et al. 2013; Tamalene 2014; Kelly et al. 2017). The population of $C$. nicobarica continues to decline because of habitat degradation and hunting to be used as pets or for the sale of gals (Birdlife International 2012; Kelly et al. 2017). Two other species, L. sueurii and D. densus have been categorized as endemic to Wallacea (Coathes and Bishop 2000).

In addition to these three species, there are several other species protected by Indonesian Law, unique and much in demand by birdwatchers. P. elegans, for example, is an icon in Kerandangan Nature Park; attract both local and overseas birdwatchers (Suana et al. 2016). M. reinwardt is a unique bird; it does not incubate its eggs but builds a nest of mounds on the ground that are useful for generating heat for incubation and prevention of egg damage from fungi (Dekker et al. 2000). Although internationally the $M$. reinwardt population is relatively stable (Birdlife International 2013), locally (in Lombok) its existence is under threat due to habitat degradation and hunting (Aminy et al. 2013).

Legalization of Gunung Tunak since 2014 with the status of Nature Park was one of the important conservation steps in protecting flora and fauna in Gunung Tunak, especially the bird community. However, conservation efforts are not only limited to establishing legalization. Conservation efforts must continue to ensure the sustainability of the flora and fauna. One of the important conservation efforts is periodical monitoring. The 2014-2016 report of the Nature Resource Conservation Center of West Nusa Tenggara (BKSDA NTB 2014, 2015, 2016), on the condition of nature parks in NTB province, did not explain in detail the condition of the bird community. This indicates the shortcoming of conservation efforts, especially the bird community. The availability of regular monitoring data is indispensable for the design of conservation plans (Gregory et al. 2003). In addition, monitoring and evaluating the abundance and distribution of bird community in regional units can help determine the best regional units to maintain bird populations and their habitats and be able to ascertain the conservation priority objects in an area (NABCI 2011).

\section{ACKNOWLEDGEMENTS}

The authors thank the Gunung Tunak Nature Park for permission to do the work in the area. All of the work done was funded by Faculty of education, University of Mataram. Also, the fieldwork assistances was done by the 
Berugaq Organik Narmada (BON) Team: Rizky Regina Kawirian, Lalu Wirajagat, Noarmuda Setiawan, and Febrian Kusuma Atma Negara.

\section{REFERENCES}

Aminy MR, Soma IG, Widyastuti SK. 2013. Keberadaan Burung Gosong Kaki-Oranye (Megapodius reinwardt) di Gili Trawangan, Kabupaten Lombok Utara. Indonesia Medicus Veterinus 2: 479-478. [Indonesian]

Andrén H. 1994. Effects of habitat fragmentation on birds and mammals in landscapes with different proportions of suitable habitat: A review. Oikos, 7: 355-366.

Barnosky AD, Hadly EA, Bascompte J, Berlow EL, Brown JH, Fortelius M. 2012. Approaching a state shift in earth's biosphere. Nature, 486:52-58.

BirdLife International. 2012. Caloenas nicobarica. The IUCN Red List of Threatened Species 2012:e.T22690974A38288253.

BirdLife International. 2013. Megapodius reinwardt. The IUCN Red List of Threatened Species 2013: e.T22734302A50448841.

BKSDA NTB. 2014. Buku Statistik Balai Konservasi Sumber Daya Alam Nusa Tenggara Barat Tahun 2014. Balai BKSDA NTB. Mataram. [Indonesian]

BKSDA NTB. 2015. Buku Statistik Balai Konservasi Sumber Daya Alam Nusa Tenggara Barat Tahun 2015. Balai BKSDA NTB. Mataram. [Indonesian]

BKSDA NTB. 2016. Buku Statistik Balai Konservasi Sumber Daya Alam Nusa Tenggara Barat Tahun 2016. Balai BKSDA NTB. Mataram. [Indonesian]

Catterall CP. 1985. Winter energy deficits and the importance of fruit versus insects in a tropical island bird population. Austral Ecol 10 265-279

Coates BJ, Bishop KD. 2000. Burung-burung di Kawasan Wallacea Bogor: BirdLife International Indonesia Programme. [Indonesian]

Dekker RWRJ, Fuller RA, Baker G. 2000. Megapodes. Status Survey and Conservation Action Plan 2000-2004. Megapode Specialist Group. IUCN, Gland, Swítzerland and Cambridge, UK, and the World Pheasant Association.

Dias DFC, Ribeiro MC, Felber YT, Cintra ALP, De Souza NS, Hasui EÂ. 2016. Beauty before age: landscape factors influence bird functional diversity in naturally regenerating fragments, but regeneration age does not. Restor Ecol 24: 259-270.

Fry CH, Keith S, Urban EK. 2000. The Birds of Africa. Volume VI. Academic Press, London

Gregory RD, Noble D, Field R, Marchant J, Raven M, Gibbons DW 2003. Using birds as indicators of biodiversity. Ornis Hungarica 12 13: $11-24$.

Hadiprayitno G, Mertha IG, Ilhamdi ML. 2016. Species richness and birds conservation priority in Mount Rinjani Areas. Biosaintifika: J Biol Biol Education 8: 270-277.

Higgins PJ, Peter JM, Steele WK. 2001. Handbook of Australian, New Zealand \& Antarctic Birds. Melbourne. Oxford University Press.

Hockey PAR, Dean WRJ, Ryan PG. 2005. Roberts' Birds of Southern Africa. $7^{\text {th }}$ ed. The Trustees of the John Voelker Bird Book Fund, Cape Town.

Hooper DU, Adair EC, Cardinale BJ, Byrnes JE, Hungate BA, Matulich K. 2012. A global synthesis reveals biodiversity loss as a major driver of ecosystem change. Nature 486: 105-108.

Howes J, Bakewell D, Noor YR. 2003. Panduan Studi Burung Pantai. Bogor: Wetlands International-Indonesia Programme. [Indonesian]

Hughes TP, Linares C, Dakos V, van de Leemput IA, van Nes EH. 2013 Living dangerously on borrowed time during slow, unrecognized regime shifts. Trends Ecol Evol 28:149-155.

Kelly J, Rahman, Grass I, Tasirin JS, Waltert M. 2017. Avifaunal status updates, range extensions and potential new taxa on the lesser Sangihe and Talaud islands, Indonesia. Raffles Bull Zool 65: 482496.

Krebs CJ. 2009. Ecology: The Experimental Analysis of Distribution and Abundance (Sixth Edition). Pearson International Edition, USA.

Larsen JL, Heldbjerg H, Eskildsen, A. 2011. Improving national habitat specific biodiversity indicators using relative habitat use for common birds. Ecol Ind 11: 1459-1466.
Leadley P, Proença V, Fernández-Manjarrés J, Pereira HM, Alkemade R, Biggs. 2014. Interacting regional scale regime shifts for biodiversity and ecosystem services. BioScience 20: 1-15.

Lindenmayer D, Blanchard W, Tennant P, Barton P, Ikin K, Mortelliti A. 2015. Richness is not all: How changes in avian functional diversity reflect major landscape modification caused by pine plantations. Divers Distrib 21: 836- 847

Lindenmayer DB, Margules CR, Botkin DB. 2000. Indications of biodiversity for ecologically sustainable forest management. Conserv Biol 14: 941-950.

Luck GW, Carter A, Smallbone L. 2013. Changes in bird functional diversity across multiple land use: Interpretations of functional redundancy depend on functional group identity. PLoS One 8: 11.

Li X, Zhang X, Xu X, Lv S, Zhao Y, Hou C, Chen B, Yang G, Chen D. 2016. Bird diversity in the buffer zone of the largest coastal nature reserve of China and conservation implications. Pakistan J Zool 48: 1193-1199.

Liu D, Lu J, Deng H. 2004. Relationship between environmental changes and population dynamics of birds in Chongqing. Chinese J. Southw. Agric Univ Nat Sci 26: 84-87.

Manica LT, Telles M, Dias MM. 2010. Bird richness and composition in a Cerrado fragment in the State of São Paulo. Braz J Biol 70: 243-254.

Melo M, Warren BH, Jones PJ. 2011. Rapid parallel evolution of aberrant traits in the diversification of the Gulf of Guinea white-eyes (Aves, Zosteropidae). Mol Ecol 20: 4953-4967.

Mittermeier JC, Cottee-Jones HEW, Purba EC, Ashuri NM, Hesdianti E, Supriatna J. 2013. A survey of the avifauna of Obi island, North Moluccas, Indonesia. Forktail 29: 128-137.

Moyle RG, Filardi CE, Smith CE, Diamond J. 2009. Explosive Pleistocene diversification and hemispheric expansion of a "great speciator". Proc Natl Acad Sci USA 106: 1863 - 1868

Myers SD, Bishop KD. 2005. A review of historic and recent bird records from Lombok, Indonesia. Forktail 21: 147-160.

North American Bird Conservation Initiative (NABCI). 2011. The State of the Birds 2011 Report on Public Lands and Waters, United States of America. U.S. Department of Interior, Washington, D.C., USA.

Palmer GC, Fitzsimons JA, Antos MJ, White JG. 2008. Determinants of native avian richness in suburban remnant vegetation: Implications for conservation planning. Biol Conserv 141: 2329-2341.

Peraturan Menteri Lingkungan Hidup dan Kehutanan Nomor 106 Tahun 2018 Jenis Tumbuhan Dan Satwa Yang Dilindungi. [Indonesian]

Rahayuningsih M., Mardiastuti A, Prasetyo LB, Mulyani YA. 2007. Bird Community in Burung Island, Karimunjawa National Park, Central Java. Biodiversitas 8: 183-187.

Reis E, López-Iborra GM, Pinheiro RT. 2012. Changes in bird species richness through different levels of urbanization: Implications for biodiversity conservation and garden design in Central Brazil. Landsc. Urban Plan107: 31-42.

Roy MB, Chatterjee D, Mukherjee T, Roy PK. 2016. Environmental threat to wetland Bio-Diversity On migratory bird: A case study of periurban area Of West Bengal. Asian J Curr Res 1: 30-38

Scott SN, Clegg SM, Blomberg SP. Kikkawa J, Owens IPF. 2003. Morphological shifts in island-dwelling birds: the roles of generalist foraging and niche expansion. Evolution 57: 2147-2156.

Suana IW, Ahyadi H, Amin, S, Kalih LATTWS, Hadiprayitno G. 2016. Birdwatching in Kerandangan Nature Park, Lombok, Nusa Tenggara Barat, Indonesia. BirdingASIA 26: 8-16.

Tamalene MN. 2014. A Bird Conservation for Educational Tourism in National Park Aketajawe Lolobata Halmahera, Indonesia. IntJ Plant Res 4:14-19.

Tripathi P, Tiwari A, Singh SP, Agnihotri S. 2015. Study on bird diversity of Chuhiya Forest, District Rewa, Madhya Pradesh, India. Int J Pharm Life Sci 6: 4304-4316.

Wahyuni TE, Mildranaya E. 2010. Panduan Wisata Alam di Kawasan Konservasi Nusa Tenggara Barat. BKSDA NTB, Mataram. [Indonesian]

Warren BH, Bermingham E, Prys-Jones RP, Thébaud C. 2006. Immigration, species radiation and extinction in a highly diverse songbird lineage: white-eyes on Indian Ocean islands. Mol Ecol 15: $3769-3786$

Zakaria M, Rajpar MN. 2015. Assessing the fauna diversity of Marudu Bay Mangrove Forest, Sabah, Malaysia, for future conservation. Diversity 7: 137-148. 